\title{
Involving cross-border organized crime networks from ex-Soviet sources in support of terrorism and their influence on regional economic development
}

\author{
Marius TRĂISTARU \\ Bucharest University of Economic Studies, Bucharest, Romania \\ marius_raistaru@yahoo.com
}

\begin{abstract}
This paper indicates how the actions of organized crime networks (especially the former the former Soviet Union) can affect, from an economic point of view, the elaboration of policies to combat transnational terrorism. Transnational organized crime poses a significant and growing threat to national and international security, with dire implications for public safety, public health, democratic institutions, and economic stability across the globe. Not only are criminal networks expanding, but they also are diversifying their activities, resulting in the convergence of threats that were once distinct and today have explosive and destabilizing effects. Ex-soviet organized crime networks represent a significant threat to economic growth and democratic institutions. Nuclear material trafficking is an especially prominent concern in the former Soviet Union. Because some terrorist-extremist organizations are criminal groups that have a specific organization, logistics, specific training and education systems that cannot work without having material and financial resources. As a result, one of the most effective ways to fight the threat of terrorist organizations is to combat terrorism financing. Within the European Union, the primary responsibility for combating terrorist financing lies with the Member States. However, the EU can and should play a supporting role in helping to respond to the transnational nature of the threat.
\end{abstract}

Keywords: cross-border crime, impact of cross-border crime, transnational terrorism, economic development, European Union, democracy, terrorist organizations.

\section{Introduction}

Terrorism is the premeditated use or threat of use of violence by individuals or subnational groups to obtain a political or social objective through the intimidation of a large audience, beyond that of the immediate victim.

An essential aspect of this definition concerns the presence of a political objective that the terrorist acts or campaigns of terror are designed to achieve. Incidents that have no specific political demand are criminal rather than terrorist acts - e.g., extortion for profit.

Terrorism is an every day threat, a system of asymetric actions which brings about a seemingly no way out situation. Experience that dat been achieved so far in the international war against terrorism pointed out that a different outlook is needed in order to be efficient in this confrontation. Such an outlook should include specific objectives and measures possibly adopted by international operating theaters.

Another crucial ingredient is the use of extranormal violence or brutality to capture news headlines. As the public becomes numb to their acts of violence, terrorists respond with more ghastly actions to recapture media attention.

Although the motives of terrorists may differ, their actions follow a standard pattern with terrorist incidents assuming a variety of forms: airplane hijackings, kidnappings, assassinations, threats, bombings, and suicide attacks. Terrorist attacks are intended to apply sufficient pressures to a government so that it grants political concessions. If a besieged government views the anticipated costs of future terrorist actions as greater than the costs of conceding to terrorist demands, then a government will make some accommodation. 
Another crucial ingredient is the use of extranormal violence or brutality to capture news headlines. As the public becomes numb to their acts of violence, terrorists respond with more ghastly actions to recapture media attention. Thus, the escalation experienced on 11 September 2001 (9/11) came as no surprise to those who study terrorism. 9/11 constituted a turning point at international level, which inoculated a series of "threats" at the level of public opinion ("generalized insecurity", "endless threat" or "how is the friend distinguished from the enemy?") which were duplicated by the major challenges of the "new world order" ("how are theaters of war delimited?" or "how is the duration of hostilities evaluated?") on the grounds that when the enemy is the terrorist, it seems perfectly impossible for him to be located or his strategy of action to be anticipated. the significant effect of this international "tsunami" was the change of paradigm (philosophy) regarding the approach to terrorism, being able to speak of the end of the age of territoriality (symbolic end inscribed in the collective memory) because notions as force/weakness or threat/security have become "extraterritorial issues that exceed the application of territorial solutions".

Terrorism comes in two essential types: domestic and transnational. Domestic terrorism is homegrown with consequences for just the host country, its institutions, citizens, property, and policies. In a domestic terrorist incident, the victim and perpetrators are from the host country. The Oklahoma City bombing on April 19, 1995 was a domestic terrorist event as was the kidnapping of members of Parliament by Colombian terrorists. Many ethno-nationalist conflicts (e.g., the Tamils of Sri Lanka) are associated with mostly domestic terrorism, unless the rebels desire to target citizens from other countries to publicize their cause to the world. Domestic events tend to outnumber transnational terrorist events by eight to one (Enders and Sandler, 2006).

In contrast, transnational terrorism involves more than one country. This international aspect can stem from the victims, targets, institutions, supporters, terrorists, or implications. For example, $9 / 11$ is a transnational terrorist event because the victims were from many different countries, the mission was financed and planned from abroad, the terrorists were foreigners, and the implications of the events (e.g., financial and security) were global. A hijacking that originates in one country but terminates in another country is an instance of transnational terrorism as is the assassination for political ends of a foreigner on a city street. Transnational terrorist attacks often entail transboundary externalities: actions or authorities in one country impose uncompensated consequences on person or property in another country.

Apart from these consequences (which include victims, destroyed buildings, an increased level of anxiety) we can talk about important economic costs. Clearly, the attacks on September 11,2001 (henceforth, 9/11) had significant costs that have been estimated to be in the range of $\$ 80$ to $\$ 90$ billion when subsequent economic losses in lost wages, workman's compensation, and reduced commerce are included (Kunreuther, Michel-Kerjan and Porter, 2003).

Studies over the last decade have established that internal conflicts can have significant economic consequences in terms of reduced growth within a conflict-ridden country (Collier and Hoeffler, 2004; Collier et al., 2003; Collier and Sambanis, 2002) and in neighboring countries (Murdoch and Sandler, 2002, 2004).

In the current international context, there is an exponential increase in organized crime and terrorism, which is why it has become necessary to better understand the factors that caused this intensification. Relations that have developed between transnational organised crime and terrorism are not static, but have evolved over the past decade into a continuum that inherently seeks to trace how organisational dynamics and the operational nature of both phenomena changes over time (Makarova, 2004). 
The crime - terror nexus is placed on a continuum (Figure 1) precisely because it illustrates the fact that a single group can slide up and down the scale - between what is traditionally referred to as organised crime and terrorism - depending on the environment in which it operates.

PICBE | 977

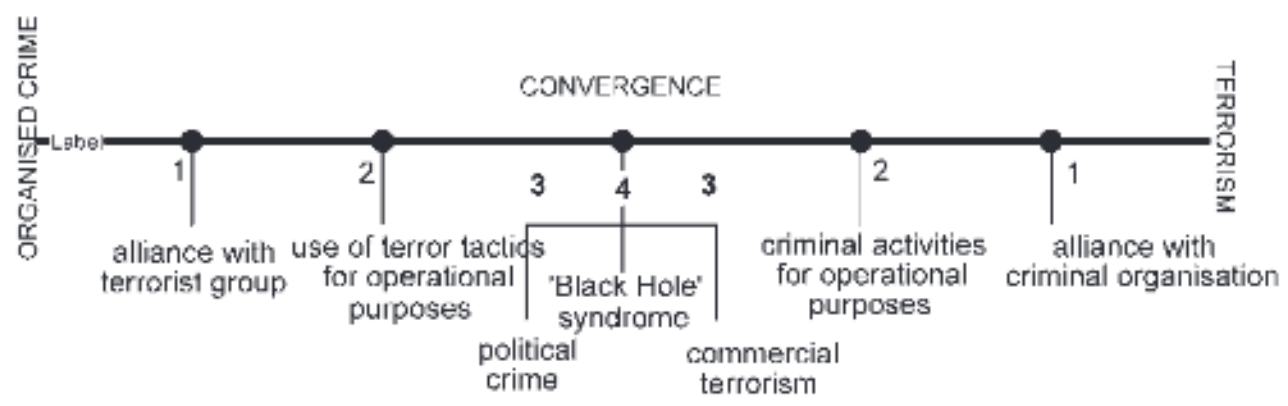

Figure 1 The Crime Terror Continuum

Source: www.iracm.com.

As depicted in Figure 1, organised crime and terrorism exist on the same plane, and thus are theoretically capable of converging at a central point. Organised crime is situated on the far left, with traditional terrorism situated on the far right - each holding distinct and separate positions. At the fulcrum of the continuum lies the point of "convergence", where a single entity simultaneously exhibits criminal and terrorist characteristics. In assessing the various relationships that have developed between criminally and politically motivated groups, seven categories are discernible - each of which are illustrated as distinct points along the continuum. These seven points, however, can be divided into four general groups: alliances (1), operational motivations (2), convergence (3), and the 'black hole' (4).

The central objective of the research paper is to increase the degree of knowledge regarding the evolution and impact of cross-border crime on the economic and social development in Romania and in the region, by adapting and using methodologies implemented and tested in other states of the world (in particular, in western Europe and US).

The main research hypothesis is that the phenomenon of cross-border crime has a major impact on regional economic-social development, and a number of factors (economic, social, administrative, institutional or legislative) have a decisive influence on increasing the impact of the actions of cross-border organized crime groups or reducing it through prevention and control.

Secondary assumptions argue that the effectiveness of controlling cross-border crime increases through the complementarity of legal actions with regional economic development measures and demonstrates that poverty, social exclusion and corruption amplify the impact of the phenomenon on citizens.

\section{The history of cross-border organized crime networks from ex-Soviet sources}


The current phenomenon of organized crime in the former Soviet republics has not appeared on a barren terrain, as it is the result of a time evolution of the activity of the smuggling groups, thieves and robbers who have dominated the interloping world of the previous regimes in Russia.

The founders of the Soviet state not only admired the ethos of the criminal gangs mentioned, but they also used the members of some of them in their revolutionary actions, being involved in blackmail, kidnapping, robbery and other criminal acts/acts, for the purpose of fundraising.

PICBE | 978

The centralized planned economy from the ex-Soviet republics, through the shortcomings created in the supply of goods of strict necessity for the population, favored the development of the phenomenon of the "black market" and implicitly of the criminal gangs. In turn, the "perestroika" initiated by former President Miahail Gorbachev not only did not disrupt the activity of criminal networks but, on the contrary, by destroying the mechanisms of political, economic and social control, it facilitated the association of the exponents of the interlocking world of the Soviet states. The collapse of the Communist Party, together with the Soviet states, also affected the criminal justice system. At the same time, the end of the cold war has made it possible for criminal organizations in the former Soviet republics to engage in specific transnational activities of large scale.

Former Soviet authorities officially recognized the existence of organized crime during the communist regime only at the end of 1988, when they mentioned its three stages, namely: primitive, middle-level and mafia-type.

Criminal groups, located mainly in Russia, are present in most of the former Soviet republics, their proliferation and expansion rate being quite impressive. Thus, according to experts, in 1994, there were 5,691 criminal groups in Russia, their number reaching 9,500 in 2000, compared to 750 in 1990. Russian criminal organizations have a true "army", with over 150,000 members for which about 3 million people work. Also known as the "criminal revolution", the organized crime phenomenon, considered as the most explosive force resulting from the collapse of the communist system, a by-product of the current settlements and prefaces, acts practically in all young democracies, in every class, blanket or social category, as well as at the level of the entire central and local administration of the former Soviet republics in the process of restructuring.

Relevant, regarding the power accumulated by the criminal groups at the level of the Russian Federation, are the data and information from official sources, according to which $40 \%$ of the private companies and $60 \%$ of the state companies are under their control (over 2,000 economic units with capital state, 4,000 joint stock companies, 7,000 small businesses, 7,700 markets and fairs), half of the number of commercial banks and stock exchanges, 50-80\% of shops, hotels, restaurants, casinos, warehouses and public services in Moscow and the whole commercial network from St. Petersburg. Russian criminal organizations have reached 30-40\% of Russia's GDP, controlling, almost entirely, the market of this country and expanding its operations in the rest of Europe, especially in the eastern and central area, as well as on other continents, especially in North and South America.

After the fall of the Soviet Union, criminal-political formations expanded drastically in the newly emerging Balkan democracies (including Romania). The weak government structures, the deteriorating domestic economy and the vulnerable government institutions made the Balkan region a safe haven for war profiteers, career criminals and fundamental Islamists (Arsovska and Basha, 2012).

\section{Forms of manifestation of cross-border organized crime}


The notion of "crime" is often used in cases of a plurality of criminal acts, a statistical totality of them. As a continuity, we come to the conclusion that at national and European legislative level we do not find unanimity regarding the outline of the concepts of crime and the centralized methods of combating it.

EU SOCTA 2017 highlights the fact that organized crime inside the EU involves people from over 180 countries, who reside inside or outside the EU $40 \%$ of the suspected persons are not citizens of the Member States. The main trafficking routes of organized crime that pose a threat originate outside the EU (in particular, the former Soviet space).

\section{Computer crime}

By its very nature, cybercrime is international: victims, criminals and evidence are often located in different countries, being under several jurisdictions. EU Member States have shown a particular interest in the priority of cybercrime, as evidenced by the number of operational action plans established in the areas of cyber-attacks, online sexual exploitation of children and payment card fraud.

Other measures include exploring possible solutions to remove obstacles to criminal investigations against cybercrime, by identifying specific initiatives regarding access to evidence and information. Cooperation in the fight against cybercrime should continue to focus on identifying victims and protecting them, based on the current set of victims' rights set out in EU law and current best practices.

\section{Drug production, trafficking and distribution}

The illicit drug market is still the largest criminal market in the EU. The EU SOCTA 2017 shows that more than one third of the criminal groups operating in the EU are involved in the production, trafficking or distribution of various types of drugs. The EU retail drug market is estimated at least EUR 24 billion per year. Drug trafficking also supports the informal economy and leads to violence and other illegal activities and is the cause of major social problems.

\section{Illegal introduction of migrants}

Illegal entry of migrants into the EU is today one of the fastest growing forms of organized crime (one of the main "basins" being the former Soviet space). This, in addition to fueling irregular migration into the EU - thus affecting border security and undermining migration management - is a serious form of crime, whereby migrants are increasingly exposed to violence, exploitation and the risk of loss of life.

\section{Organized crime against heritage}

This form of manifestation refers to a series of various criminal activities carried out by organized, mobile, highly specialized criminal groups operating throughout the EU, in particular through robberies, thefts and organized robberies, as well as through crime related to vehicles. However, as individual incidents are often considered minor offenses, they are not sufficiently investigated. The increase in the number of burglaries of houses that can be attributed to itinerant criminal groups coming mainly from South East and Eastern Europe is a major concern for law enforcement authorities. In order to combat this highly mobile form of crime, cooperation between law enforcement authorities within the EU, but also with neighboring partner countries, is a priority.

\section{Human trafficking}

Over the last few decades, human trafficking has become the third major form of cross-border crime and a major source of income for international criminal organizations. For over 10 years, human trafficking has been a priority threat to the EU and should continue to be considered in the next policy cycle. This is one of the worst forms of organized crime, and is a flagrant violation of 
human rights, but it is one of the most profitable criminal markets. Traffickers rely heavily on document fraud in order to carry out their trafficking activities.

Most often, the money from this type of crime is used to support other illegal activities such as corruption and other forms of cross-border crime or to pay network members, to create the latest generation logistics needed for communication and transportation activities, in order to bribe some state agents and often to provide the necessary legal assistance to traffickers who are criminally investigated in order to obtain their freedom or to negotiate a sentence as favorable as possible.

\section{Firearms trafficking}

Black markets in former Soviet countries are the primary source of firearms for terrorist and criminal purposes. The online sale of illegal firearms on Darknet and their delivery through regular postal services are the most common forms of firearms trafficking in the EU.

Treating firearms trafficking as a priority in the current EU policy cycle has resulted in a stronger commitment of Member States (increasing number of participating countries from 12 to 22) and increased involvement of customs authorities.

\section{Cross-border VAT fraud}

Organized crime groups annually cause between 40 and 60 billion euros of revenue losses through cross-border VAT fraud, and $2 \%$ of these groups are responsible for $80 \%$ of intra-community fraud with ghost companies. Fraud mechanisms are extremely complex and difficult to detect and therefore require a coordinated approach by tax administrations and law enforcement agencies.

\section{Offenses against the environment}

The value of the damages caused by the crimes against the environment is between 91 USD and 258 billion USD annually, and the growth rate of these crimes is 2-3 times higher than the growth rate of the world economy. They rank fourth in the world in importance, after drug trafficking, counterfeiting and human trafficking.

\section{The particularities of ex-Soviet crime and the financing of terrorist actions}

The origin of resources that allow terrorist groups to act does not come exclusively from money laundering. In the matter of terrorism, money laundering is considered a directly related crime. By common sense, money laundering is understood as masking and concealing the origin of the values and assets obtained with illicit activities introduced into the financial economic system with an appearance of legality. This perception is somewhat consensual in the academic field.

Maia (2004) defines the expression "the complex of operations integrated through the stages of transformation, dissimulation and integration of goods, rights and values in order to make legitimate goods derived from criminal offenses."

In Welter's lesson (2001), it is a process by which the illicit origin of certain goods is hidden for their introduction into the legal market. "

The value of the damages caused by the crimes against the environment is between 91 USD and 258 billion USD annually, and the growth rate of these crimes is 2-3 times higher than the growth rate of the world economy. They rank fourth in the world in importance, after drug trafficking, counterfeiting and human trafficking. Experts believe that the sources of the fabulous financial funds currently available to Russian criminal organizations are generally the same as those of traditional Mafia gangs, being involved in the whole spectrum of acts and facts specific to organized crime, from pimping, extortion, blackmail, robberies and attacks by "rackets", up to drug trafficking, illegal trade in weapons, explosives, ammunition, radioactive substances, falsification 
of various documents and means of payment, sale of counterfeit goods, trafficking in persons abroad and operations money laundering.

Following the consolidation of the position on the illicit market of the Russian Federation, the Russian Mafia organizations gradually expanded the scope of influence, initially in the Baltic republics and the countries of Central and Eastern Europe (whose economic, social, political and legislative structural reforms provide favorable conditions. organized crime), and subsequently in the southern, western and northern states of the continent, where there were already indigenous groups or networks of the Italian and Chinese mafia with which, during the course, they concluded a series of secret agreements and agreements.

The following characteristics regarding the presence and activity of Russian criminal groups in Europe are derived from the reading of the specialized literature:

- the use, to a greater extent, by the Russian mafia organizations, of the territory of Poland, Czech Republic, Slovakia, Hungary, Bulgaria, Romania and Albania as storage points for drugs destined for the West;

- transforming the cities of Prague and Warsaw into bases of operations of both the Russian and Italian mafias for the introduction of drugs in the western European countries; - the use by the networks of drug traffickers, under the control of the Russian mafia organizations, of the airports in Prague, Bucharest and Sofia, from where the "cargo" is then transported by land to Western Europe;

- the control exerted by the Russian mafia organizations, in cooperation with the Ukrainian, Belarussian, Armenian, Georgian and Azeri, on the trafficking of weapons and radioactive substances, the trade in counterfeit consumer goods, as well as the trafficking in counterfeit means, practiced in the countries from eastern and central Europe;

- the Russian Mafia's exercise of the monopoly on trafficking stolen cars from the West, towards the Eastern European countries and the Middle East area;

- taking over the control of the Russian mobsters of the majority of the prostitution networks operating underground in Hungary, Poland, Czech Republic, Slovakia, Romania and Bulgaria;

- a phenomenon that causes increasing anxiety is the extension of the influence and operations of the Russian mafia organizations in the western states, in the USA and in the countries of the third world.

All these illegal methods, whose main purpose is to finance organized crime activities, constitute a threat to the national security of Romania, the organizations of ex-Soviet origin also aiming to obtain funds by carrying out activities, licenses (trade, import-export) or illicit (drug, arms trafficking, illegal migration, smuggling, etc.) in our country.

The next step of the offensive of the Russian mafia organizations will be the investment of illegally obtained money in state and private companies in the West, in actions and areas belonging mainly and traditionally to the international mafia, such as the construction of houses, offices and hotels, recycling of residues and toxic substances of any kind nature, purchasing restaurants, casinos, tolerance houses and shops.

\section{Measures adopted by Romania in the fight against this type of terrorist phenomenon}

The effects of the actions of the ex-Soviet organized crime groups on Romania could be substantial due to the problems of functioning of the democracy existing in the last 30 years, reflected in a low level of trust in the institutions, and the measures taken should have been given priority this type 
of vulnerability. Thus, in order to limit the negative effects of the influence of the ex-Soviet crossborder organized crime, the following categories of measures were highlighted:

- measures to increase the transparency of institutions with national security responsibilities. In this case, an attempt was made to attach particular importance to the idea that changes in legislation with implications for national security must take place in high conditions of transparency;

- informing the population about the measures already provided by the legislative framework, as

PICBE | 982 well as identifying ways to ensure a better implementation of the legislation regarding cooperation between institutions;

- measures to improve the mechanisms for the political representation of citizens in order to reduce the chances of radicalization of certain categories of citizens and to increase the level of trust in political institutions with responsibilities for national security;

- rapid exchange of information between countries involved in combating this phenomenon of suspects and cooperation in identifying sources of funding for members of ex-Soviet organized crime groups.

On the other hand, the regional economy can be affected by external factors, associated with the phenomenon of cross-border crime, both through financial circuits aimed at concealing the amounts obtained illegally, and by stimulating corruption.

The response to combating this phenomenon is multidisciplinary and involves the involvement of a large number of central/local public institutions, as well as citizens, civic, religious or social organizations so that their activity is complementary, and their overlaps and/or contradictions are, as far as possible, diminished or eliminated. At the same time, a greater concern for the more judicious distribution of budgetary resources between the different actors is absolutely necessary, in order to ensure administrative efficiency and capitalization with maximum impact of resources. Complementarity should not only be achieved theoretically, at European level, but must be supported, monitored and promoted at regional, national and local level, being a critical aspect in the prevention and control of cross-border crime, as specific measures need to be supplemented with policies and programs in the field of economic development.

\section{Conclusion}

It is necessary to conduct cost-benefit or cost-effectiveness analyzes for projects and interventions regarding combating cross-border crime so that the process of public policy development has the support and up-to-date information. At the same time, the studies regarding the costs of this phenomenon must be financially supported and included in government programs, and their results analyzed compared with the conclusions of international research on the same subject.

Specific institutional activities for managing cross-border crime must be based, to a greater extent, on scientific tools, and the distance between practitioners and researchers must be reduced, in order to streamline the process of developing and implementing policies and programs to combat the phenomenon. of organized crime across borders.

Considering the above, it is concluded that although the concentrated effort of governments and international community bodies to combat the various sources of terrorist financing, the problem persists.

Combating any form of cross-border crime involves activities of international cooperation, as well as the application of the principle of transnationality for effective cooperation.

Even Romania has tried to act towards respecting international commitments in the spirit of loyalty and prudence, but at the same time, it has sought to identify a balance between national commitments and sovereignty.

DOI: 10.2478/picbe-2020-0092, pp. 975-983, ISSN 2558-9652| Proceedings of the $14^{\text {th }}$ International Conference on Business Excellence 2020 
At the same time, the Romanian authorities understood that transparency and broad consultation are important in order to find the best ways to address the threats and to implement international measures.

\section{References}

Albu P. (2007), Organized Crime in the Transition Period - A Major Threat to the International Security Address.

Arsovska J. \& Basha D. (2012), Globalizing the Western Balkans: Transnational Crime, Fundamental Islam and Unholy Alliances.

Collier P. \& Hoeffler A. (2004), Greed and Grievance in Civil War, Oxford Economic.

Collier P. \& Sambanis N. (2002), Understanding Civil Wars: A New Agenda.

Collier P., Elliott V. L., Hegre H., Hoeffler A., Reynal-Querol M. \& SAMBANIS N. (2003), Breaking the Conflict Trap: Civil War and Development Policy.

Kunreuther H., Erwann M.K. \&, Beverly P. (2003), Assessing, Managing and Financing Extreme Events: Dealing with Terrorism.

Makarenko T. (2004), The Crime - Terror Continuum: Tracingthe Interplay between Transnational Organised Crime and terrorism.

Murdoch J. C. \& Sandler T. (2002), Economic Growth, Civil Wars, and Spatial Spillovers.

Murdoch J. C. \& Sandler T. (2004), Civil Wars and Economic Growth: Spatial Spillovers.

Olaru M. (2005), Types of Terrorism - Particularities \& Determinant Factors.

Sandler T. \& Enders W. (2002), An Economic Perspective on Transnational Terrorism.

Sandler T. \& Enders W. (2006), The Political Economy of Terrorism.

Sandler T. \& Enders W. (2010), Economic Consequences of Terrorism in Developed and Developing Countries: an Overview.

Cross-Border and Transnational Criminality: Trends and Current Forms of Presentation, Problems of Prevention and Combat - Material of the International Scientific-Practical Conference, Chișinău 2018.

Report from the Commission to the European Parliament, The European Council and the Council. Available at: https:/ec.europa.eu/transparency/regdoc/rep/1/2017/RO/COM-2017-213-F1RO-MAIN-PART-1.PDF. 